- Technological Report -

\title{
エリソルビン酸を還元剤とする無電解金めっき
}

\author{
倉科 匡 ${ }^{a}$, 西中山 宏 ${ }^{a}$, 金子 紀男 ${ }^{b}$, 篠原 直行 ${ }^{b}$, 縄舟 秀美 ${ }^{c}$ \\ a大和電機工業株式会社（广 392-0015 諏訪市中州 4750） \\ b信州大学工学部（† 380-8553 長野市若里4-17-1） \\ c甲南大学理学部（† 658-8501 神戸市東灘区岡本8-9-1）
}

\section{Electroless Gold Plating Using Erythorbic Acid as Reducing Agent}

\author{
Tadashi Kurashina,"a Hiroshi Nishinakayama, ${ }^{a}$ Norio KaneKo, ${ }^{b}$ \\ Naoyuki SHINOHARA, ${ }^{b}$ and Hidemi NaWAFUnE ${ }^{c}$
}

\author{
a Yamato Denki Ind.Co.,Ltd.(4750 Nakasu,Suwa-shi,Nagano 392-0015, Japan) \\ ${ }^{b}$ Faculty of Eng.,Shinshu Univ.(4-17-1 Wakasato,Nagano-shi,Nagano 380-8553, Japan) \\ 'Faculty of Sci.\& Eng.,Konan Univ.(8-9-1 Okamoto,Higashinada-ku,Kobe-shi,Hyogo 658-8501, Japan)
}

Received December 9, 2005 ; Accepted February 28, 2006

\begin{abstract}
The purpose of this investigation was to study electroless Au plating from a sulfite/thiosulfate complex bath $\left(0.015 \mathrm{M} \mathrm{Na}_{3}\left[\mathrm{Au}\left(\mathrm{SO}_{3}\right)_{2}\right]+0.1 \mathrm{M} \mathrm{Na} \mathrm{S}_{2} \mathrm{O}_{3}+0.4 \mathrm{M} \mathrm{Na} \mathrm{SO}_{3}+0.05 \mathrm{M} \mathrm{C}_{6} \mathrm{H}_{7} \mathrm{O}_{6} \mathrm{Na}+0.18 \mathrm{M} \mathrm{KOOCCH}(\mathrm{OH}) \mathrm{CH}(\mathrm{OH}) \mathrm{COONa}\right)$ using erythorbic acid as the reducing agent. Deposition rates by autocatalytic reaction and displacement reaction were increased with increasing the concentration of erythorbic acid. The deposition rate by autocatalytic reaction was increased with increasing bath temperature. The deposition rate by displacement reaction was suppressed by the addition of benzotriazole (BTA), di-sodium ethylenediaminetetraacetate (EDTA) and ethylenediamine (en). Electroless $\mathrm{Au}$ film which shows a good characteristics in the solder joint strength was obtained from a bath containing BTA, EDTA and en.
\end{abstract}

Key Words : Electroless Au Plating, Erythorbic Acid, Autocatalytic Deposition

\section{1 緒 言}

半導体実装基板の最終表面処理方法として電気金めっきが 行われてきたが, 電子機器の小型軽量化および高密度配線化 に伴って，電気的に孤立した微細回路の表面処理方法として， 厚付けが可能な自己触媒型の無電解金めっき技術の開発が望 まれている. 中でも自己触媒浴として主流を占めているシア ン化金カリウム - 水素化ホウ素化合物系浴はめっき速度, 膜 物性など優れた浴ではあるが，操作条件が高温，強アルカリ であり，さらに，ニッケル污染に弱いなど実用上の問題が残 っている. 最近では, 非シアン系, 緩和条件で操作可能で, 安定な実用性のある無電解金めっき浴の開発に関心が寄せら れ，いくつかの研究 ${ }^{1-4)}$ も行われている.

著者らは，ヒドラジン化合物を還元剤とする無電解金めっ き浴について検討した結果，自己触媒型の無電解金めっき浴 が，還元剤の酸化反応によって金めっき皮膜を析出させると 同時に, 下地の種類やめっき条件によっては置換めっき反応 も同時に起こるといった知見を得た ${ }^{5)}$. しかし，この浴は金 の析出速度が遅く，ヒドラジンが有害であることから，操業 上・作業環境上問題があった。そこで，金の析出速度に及ぼ す各種還元剤（チオ尿素，ヒドロキノン，L-アスコルビン酸） の影響について検討し，析出速度が速く作業環境上問題のな い自己触媒型無電解金めっき浴を開発した ${ }^{5)}$.
これらの結果も踏まえ，本研究では，価格的に安価であり， 作業環境上問題のないエリソルビン酸を還元剤として選択し， 電気化学的分極測定により, 金のカソード還元反応, 還元剤 のアノード酸化反応について検討した。 また，金皮膜を自己 触媒的に析出させるためのめっき条件を確立するとともに, 各種添加剂 (ベンゾトリアゾール, エチレンジアミン四酢酸 二ナトリウム二水和物, エチレンジアミン）の金の自己触媒 および置換析出速度に及ぼす影響について調査し，金めっき 皮膜に関してはワイヤープル強度やボールシェア強度等の実 装特性についても検討を行った。

\section{2 実験方法}

無電解金めっきの浴組成およびめっき条件を Table 1 に示 す.アノードおよびカソード分極曲線の測定には北斗電工製 自動分極装置 HZ-3000を使用した．作用極としては，アノー ド, カソード分極曲線の測定とも表面積 $0.4 \mathrm{dm}^{2}$ の田中貴金 属工業株式会社製金箔を使用した。対極には白金メッシュを 用い，参照電極には飽和カロメル電極を用いた。電位はこの 電極を基準とした值である。液量は $2 \mathrm{dm}^{3}$,測定温度は $65 \pm$ $1{ }^{\circ} \mathrm{C}$ とし,無攪汼で走査速度 $5 \mathrm{mV} / \mathrm{s}$ の条件で測定を行った。 なお, めっき液は溶存酸素除去のため, 測定前に $\mathrm{N}_{2}$ ガスを 20 分間通気した。 
Table 1 Basic bath composition and operating condition.

\begin{tabular}{cc}
\hline $\mathrm{Na}_{3}\left[\mathrm{Au}\left(\mathrm{SO}_{3}\right)_{2}\right]$ & $0.015 \mathrm{M}$ \\
$\mathrm{Na}_{2} \mathrm{~S}_{2} \mathrm{O}_{3} \cdot 5 \mathrm{H}_{2} \mathrm{O}$ & $0.1 \mathrm{M}$ \\
$\mathrm{Na}_{2} \mathrm{SO}_{3}$ & $0.4 \mathrm{M}$ \\
$\mathrm{C}_{6} \mathrm{H}_{7} \mathrm{O}_{6} \mathrm{Na} \cdot \mathrm{H}_{2} \mathrm{O}$ & $0.05 \mathrm{M}$ \\
$\mathrm{KOOCCH}(\mathrm{OH}) \mathrm{CH}(\mathrm{OH}) \mathrm{COONa} \cdot 4 \mathrm{H}_{2} \mathrm{O}$ & $0.18 \mathrm{M}$ \\
\hline $\mathrm{pH}$ & 7.3 \\
Bath temperature & $65^{\circ} \mathrm{C}$ \\
\hline
\end{tabular}

自己触媒型金めっきの置換および自己触媒析出量は以下に 示す方法により求めた。 めっき素地には山本鍍金試験器製純 銅板 $(20 \times 20 \mathrm{~mm})$ に無電解 Ni-P合金めっきを $5 \mu \mathrm{m}$ 施し, 更に無電解置換金めっき $0.047 \mu \mathrm{m}$ 行ったものを使用した 無電解ニッケルめっき浴は上村工業製ニムデン NPR-4を，無 電解置換金めっき浴はエヌ・イーケムキャット製 KMEXを, それぞれ用いた。この素地上にTable 1 に示しためっき浴か ら自己触媒型無電解金めっきを行った。なお，自己触媒的な 反応による金の析出に加え，ニッケルとの置換反応による金 の析出が同時に起こるため, サンプル作製後の無電解金めっ き浴中の $\mathrm{Ni}^{2+}$ 濃度をエスアイアイ・ナノテクノロジー製 ICP 発光分光分析装置SPS7800により測定し, 浴中の $\mathrm{Ni}^{2+}$ 量から 置換反応により析出したと考えられる金膜厚を算出した.

一方，自己触媒反応により析出した金めっき皮膜の膜厚は 以下に示す方法により算出した。 $\mathrm{Ni}$ 上に析出させた金を日 本エレクトロプレーティングエンジニア製ゴールドストリッ パーコンセントレイト $\mathrm{N}$ 剥離液に溶解し, 液中の金濃度は同 ICP 発光分光分析装置を用いて測定した。この值から金膜厚 を算出し，これから上記で求めた置換析出による金膜厚と前 処理による金膜厚（0.047 $\mu \mathrm{m} ）$ を差し引いた值を自己触媒反 応により析出した金膜厚とした。

金めっき皮膜の表面形態の観察には日本電子製走査型電子 顕微鏡 JSM-5600を使用した．同皮膜のX解回折測定にはリ ガク製自動 X 線回折装置RINT-2100型を用いた。測定に用い たX線は CuK $\alpha$ 線であり，管電圧は $40 \mathrm{kV}$ ，管電流は $30 \mathrm{~mA}$ とした。半田ボールシェア強度の測定は以下に示す方法によ り行った. 金めっき皮膜表面に千住金属製デルタフラックス $523 \mathrm{H}$ を塗布し，その上に同製63 $\mathrm{Sn} / 37 \mathrm{~Pb}$ 合金 $0.5 \mathrm{~mm} \phi$ は んだボールを設置する。その後，はんだボールを $230{ }^{\circ} \mathrm{Cにお}$ いて溶融接合した上で，デイジ製ボンドテスターPC2400を 用いてはんだボールシェア強度の測定を行った。また，ワイ ヤープル強度の測定には，セミコンダクターマテリアル製 $\phi$ $25 \mu \mathrm{m}$ の金線（純度 $99.99 \%$ ）を用い, ウエストボンド製マ ニュアルワイヤーボンダー $7700 \mathrm{D}$ によヅンディングを行い, レスカ製ワイヤープルテスターPTR-03Sを用いてプル強度 を測定した。

亜硫酸金ナトリウム水溶液 $[15 \%$ 亜硫酸ナトリウム $\left[\mathrm{Na}_{2} \mathrm{SO}_{3}\right], 8.83 \%$ 亜硫酸金ナトリウム $\left[\mathrm{Na}_{3}\left[\mathrm{Au}\left(\mathrm{SO}_{3}\right)_{2}\right]\right]$ は中央化学産業製試薬を用いた。また，チオ硫酸ナトリウ 厶・五水和物 $\left[\mathrm{Na}_{2} \mathrm{~S}_{2} \mathrm{O}_{3} \cdot 5 \mathrm{H}_{2} \mathrm{O}\right]$, エリソルビン酸ナトリウ 厶. 一水和物 $\left[\mathrm{C}_{6} \mathrm{H}_{7} \mathrm{O}_{6} \mathrm{Na} \cdot \mathrm{H}_{2} \mathrm{O}\right]$, 硫酸ニッケル（II）六水 和物 $\left[\mathrm{NiSO}_{4} \cdot 6 \mathrm{H}_{2} \mathrm{O}\right], 5$-メチル- $1 H$-ベンゾトリアゾール $\left[\mathrm{C}_{7} \mathrm{H}_{7} \mathrm{~N}_{3}\right]$ およびエチレンジアミン四酢酸二ナトリウム・二 水和物 $\left[\mathrm{C}_{10} \mathrm{H}_{14} \mathrm{~N}_{2} \mathrm{Na}_{2} \mathrm{O}_{8} \cdot 2 \mathrm{H}_{2} \mathrm{O}\right]$ は和光純薬製試薬を使用し た。
亜硫酸ナトリウム $\left[\mathrm{Na}_{2} \mathrm{SO}_{3}\right]$, 酒石酸カリウムナトリウ 厶. 四水和物 $\left[\mathrm{KOOCCH}(\mathrm{OH}) \mathrm{CH}(\mathrm{OH}) \mathrm{COONa} \cdot 4 \mathrm{H}_{2} \mathrm{O}\right]$ お よびエチレンジアミン $\left[\mathrm{NH}_{2} \mathrm{CH}_{2} \mathrm{CH}_{2} \mathrm{NH}_{2}\right]$ は米山薬品工業 製試薬を，それぞれ使用した。また，和光純薬製試薬の硫酸 $\left[\mathrm{H}_{2} \mathrm{SO}_{4}\right]$ を用い $\mathrm{pH}$ 調整を行った.

\section{3 結果と考察 \\ 3. 1 カソードおよびアノード分極曲線}

エリソルビン酸ナトリウムを還元剂とする無電解金めっき 浴（Table 1 ）について求めた金電極上の分極曲線を Fig. 1 に示す。曲線（1）は無電解金めっき浴から亜硫酸金ナトリ ウムを除いた浴について求めたアノード分極曲線であり, 曲 線（2）はエリソルビン酸ナトリウムを除いた浴について求 めたカソード分極曲線である. Fig. 1 より， $\mathrm{Au}^{+}$の還元は$0.15 \mathrm{~V}$ 付近から起こり, エリソルビン酸の酸化は- $0.4 \mathrm{~V}$ 付

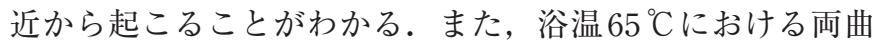
線から得られた混成電位 (Ep1) は-0.25 Vであった。この 值は本無電解金めっき浴 (Table 1) の自然電極電位にほほ 一致した. Ep1における交換電流密度は $0.21 \mathrm{~mA} / \mathrm{cm}^{2}$ であり, この值から $\mathrm{Au}^{+}+\mathrm{e}^{-} \rightarrow \mathrm{Au}$ に基づく金の析出速度を算出した 結果, $0.798 \mu \mathrm{m} / \mathrm{h}$ であった。一方, 無電解金めっき浴

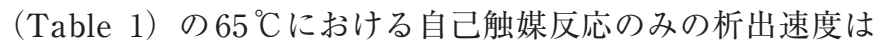
$0.718 \mu \mathrm{m} / \mathrm{h}$ であり, Ep1における交換電流密度から求めた值 とほほ一致した。これらの結果より，無電解金めっき浴 （Table 1）において，混成電位理論の成立を確認した。

加藤らの電気化学測定法による基礎的な研究 $\left.{ }^{3}, 6\right)$ によれば, 覀硫酸塩を含むチ才硫酸塩浴からの金の析出反応は，チ才硫 酸錯イオンから起こっているとしている．本無電解金めっき 浴についても亜硫酸一チ才硫酸塩系であることから，本めっ き浴中においても金はチオ硫酸錯イオンとして存在し, 金の 析出はこのチオ硫酸錯イオンの還元反応とエリソルビン酸の 酸化反応により起こっているものと考えられる.

\section{3 . 2 自己触媒反応および置換反応による金の析出量}

無電解金めっき浴（Table 1 ）の浴温とエリソルビン酸ナ トリウム濃度を変化させた時の自己触媒反応および置換反応 による金の析出速度を Fig. 2 に示す. 析出速度に及ぼす浴温 の影響は顕著であり, 浴温を上昇させることにより自己触媒 析出速度は増大した。 また, エリソルビン酸ナトリウム濃度

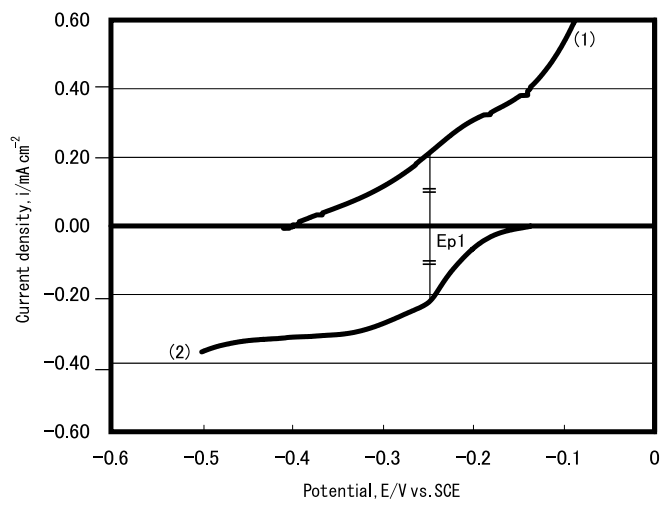

Fig. 1 Anodic and cathodic polarization curves on a gold electrode. (1) $0.1 \mathrm{M} \mathrm{Na} \mathrm{S}_{2} \mathrm{O}_{3}+0.4 \mathrm{M} \mathrm{Na} \mathrm{SO}_{3}+0.05 \mathrm{M} \mathrm{C}_{6} \mathrm{H}_{7} \mathrm{O}_{6} \mathrm{Na}$ $+0.18 \mathrm{M} \mathrm{KNaC} \mathrm{H}_{4} \mathrm{O}_{6}$ W.E. $=\mathrm{Au}$ (2) $0.015 \mathrm{M} \mathrm{Na} 3\left[\mathrm{Au}\left(\mathrm{SO}_{3}\right)_{2}\right]+0.1 \mathrm{M}$ $\mathrm{Na}_{2} \mathrm{~S}_{2} \mathrm{O}_{3}+0.4 \mathrm{M} \mathrm{Na}_{2} \mathrm{SO}_{3}+0.18 \mathrm{M} \mathrm{KNaC} \mathrm{H}_{4} \mathrm{O}_{6}$ W.E. $=\mathrm{Au}$ 


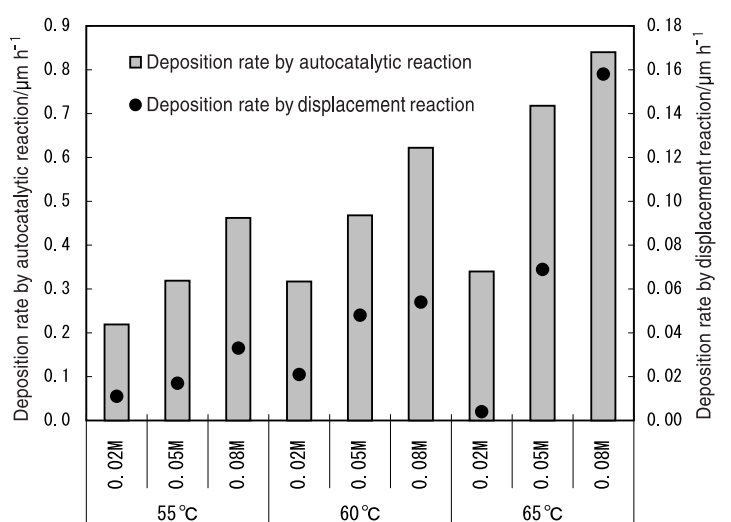

Fig. 2 Effects of bath temperature and erythorbate concentration on Au deposition rate.

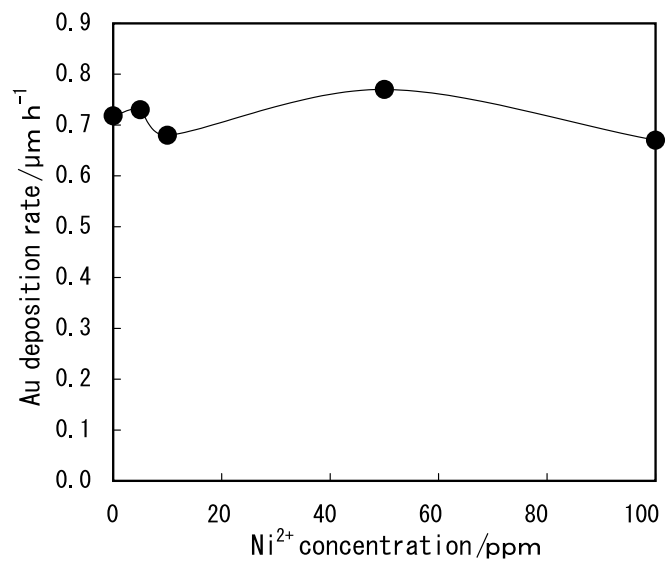

Fig. 3 Effect of $\mathrm{Ni}^{2+}$ concentration on $\mathrm{Au}$ autocatalytic deposition rate.

の増大に伴い, 自己触媒析出速度は増大し, 置換析出速度も 増大する傾向にあった。なお，エリソルビン酸ナトリウムを $0.1 \mathrm{~mol} / \mathrm{L}$ 添加した場合には浴が不安定になり，ビーカー壁 への金の析出が確認された.

無電解金めっきでは，置換金めっきのピンホール等を通じ て $\mathrm{Ni}$ 素地の溶解に伴う置換反応が同時に起こるため, 素地 である $\mathrm{Ni}$ の溶出が生じる. Fig. 3 に無電解金めっきの自己触 媒析出速度に及ぼす $\mathrm{Ni}^{2+}\left(\mathrm{NiSO}_{4} \cdot 6 \mathrm{H}_{2} \mathrm{O}\right.$ として添加）の影響 を示す。なお，今回添加した $\mathrm{Ni}^{2}+$ の最大量 $(100 \mathrm{ppm})$ は本 無電解金めっき浴の寿命として約 2.5 ターンに相当する． $\mathrm{Ni}^{2+}$ の添加により析出速度はやや低下する傾向が認められたが, その影響は小さく，浴の安定性にも特に問題がなかった.

\section{3 添加剤の影響}

無電解金めっき（Table 1） ではFig. 2 からも明らかなよ うに金の自己触媒析出と同時に置換析出も起こっており，下 地ニッケルの溶出も起きている. そこで下地ニッケルの溶出 を抑制し，金の自己触媒反応による析出効率を高めることを 目的として，無電解金めっき浴 (Table 1) に各種添加剂を 加え，金の自己触媒および置換析出速度に及ぼす添加剤の影 響について検討した。

Fig. 4 は自己触媒および置換析出速度に及ぼす5-メチル$1 H$-ベンゾトリアゾール（以下 BTA と略記）の影響を示した ものである. BTAを添加することにより, 自己触媒析出速 度は $0.718 \mu \mathrm{m} / \mathrm{h}$ から $0.43 \mu \mathrm{m} / \mathrm{h}$ に減少したが, 置換析出速度

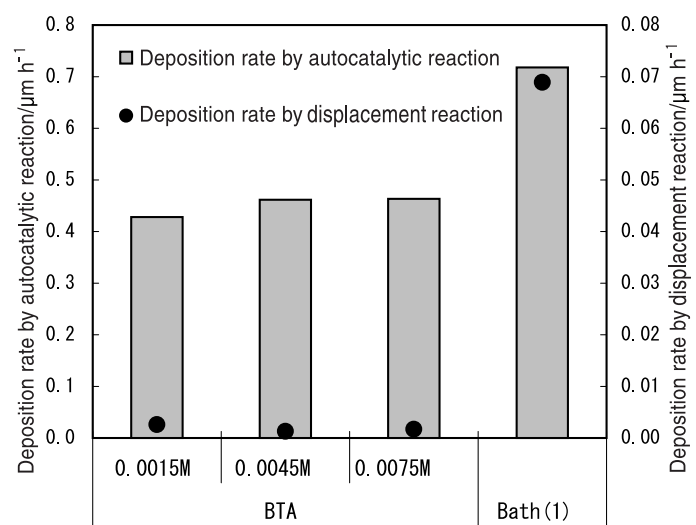

Fig. 4 Effect of BTA concentration on Au deposition rate.

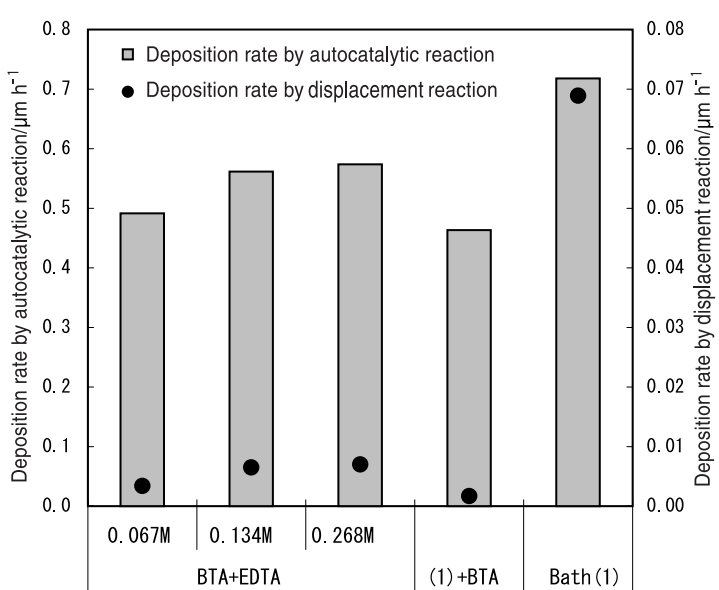

Fig. 5 Effect of EDTA concentration on Au deposition rate.

も $1 / 20$ 以下に減少した。また，BTA濃度を変化させても， 自己触媒および置換析出速度に対する影響はほとんど認めら れなかった. BTAは一般的に銅の腐食防止剂として用いら れ, 銅表面に強く吸着することがよく知られている. 本結果 より，BTAは金の表面にも吸着し，置換および自己触媒析 出反応を抑制しているものと考えられる ${ }^{3)}$.

基本浴（Table 1) にBTAおよびエチレンジアミン四酢 酸二ナトリウム・二水和物（以下EDTA と略記）の両者を 添加して同様の検討を行った。なお，この際のBTA濃度は $0.0075 \mathrm{~mol} / \mathrm{L}$ 一定とした. 無電解金めっきにおける自己触媒 および置換析出速度に及ぼすEDTA濃度の影響を Fig. 5 に示 す. EDTA濃度の増大に伴い, BTAを単独に添加した場合 に比べて自己触媒および置換析出速度が共に増大した。また， BTAのみを添加した場合と比較すると, 置換析出量が 2 4 倍となった。このように, EDTAの添加は, 特に置換析 出速度を増大させ, 実用上問題が残ることが明らかになった。

基本浴 (Table 1) にBTA (0.0075 mol/L一定), EDTA （0.067 mol/L一定）およびエチレンジアミン（以下en と略 記）を添加して同様の検討を行った. 無電解金めっきの自己 触媒および置換析出速度に及ぼす en 濃度の影響を Fig. 6 に 示す. EDTAの添加により増大した置換析出速度はenの添 加によって抑制されている。 また, en 濃度の増加に伴い, 自己触媒析出速度は増大し, 置換析出速度は減少した。一方, 覀硫酸塩とチ才硫酸塩を含むめっき浴からの金の自己触媒析 出速度に及ぼす enの影響を検討した結果, enは Au（I）亜 硫酸錯体からの金析出よりも，Au（I）チ才硫酸錯体からの 


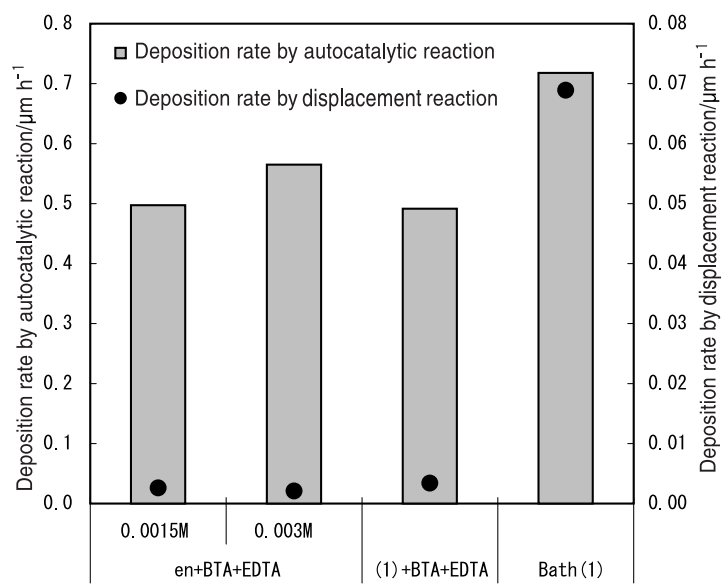

Fig. 6 Effect of en concentration on Au deposition rate.

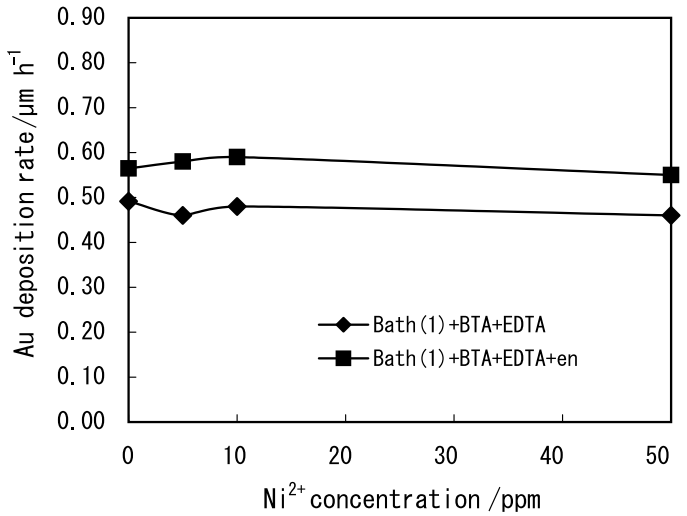

Fig. 7 Effect of $\mathrm{Ni}^{2+}$ concentration on $\mathrm{Au}$ autocatalytic deposition rate.

金析出に促進効果を持つことが報告されている ${ }^{3)}$.また，前 述のように，チオ硫酸ナトリウムを含む本めっき浴において， 金はチ才硫酸錯体として存在しているものと考えられる。こ れらのことょり, en 濃度の増大に伴い金の自己触媒析出速 度が増大したものと考えられる。

2 種類の浴（基本浴 $+\mathrm{BTA}+\mathrm{EDTA}$ ，基本浴 $+\mathrm{BTA}+$ $\mathrm{EDTA}+\mathrm{en})$ からの金の自己触媒析出速度に及ぼす $\mathrm{Ni}^{2+}$ 濃 度の影響を Fig. 7 に示す。基本浴 + BTA は， $\mathrm{Ni}^{2+}$ の添加に より浴が白濁化し, 分解した。この現象はEDTAを添加し た浴には確認されていないことから，EDTAにより $\mathrm{Ni}^{2+}$ がキ レート化され浴分解を抑制するものと考えられる. Fig. 7 よ り，金の析出速度に対する $\mathrm{Ni}^{2+}$ の影響はほとんど認められな いことがわかる.

\section{3. $4 \mathrm{Au}$ めっき皮膜の微細構造}

無電解金めっき浴（基本浴＋BTA + EDTA + en）を用い, 浴温 $65{ }^{\circ} \mathrm{C}, 50$ 分間の妨条件で膜厚 $0.5 \mu \mathrm{m}$ の金を析出さ せた.Fig. 8 （1）は，その金めっき皮膜の表面観察結果を示 したものである．表面はやや粗い粒子が観察されたが，肉眼 では均一なレモンイエローを呈していた。一方, Fig. 8 (2) は金めっき剥離後の無電解ニッケル表面の観察結果を示した ものである.ニッケル表面には点状の腐食孔の発生が観察さ れるが，これは下地置換金めっき後の表面においても同様の 腐食孔が観察されていることからこの段階で発生したものと 考えられる。

Fig. 9 は析出した金皮膜について求めた X 線回折図を示し
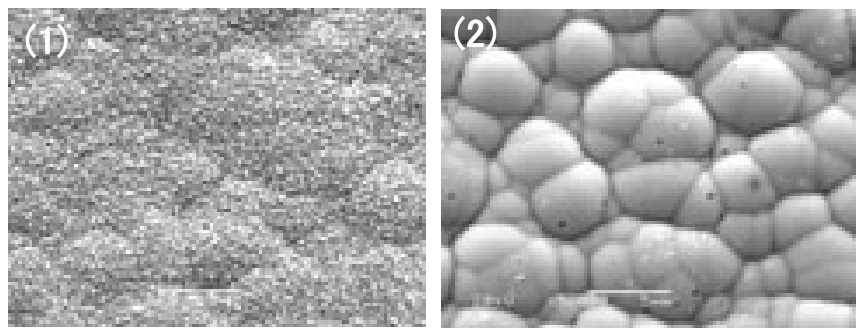

Fig. 8 Surface morphology of electroless Au deposit (1) and electroless Ni film after electroless Au film removed (2).

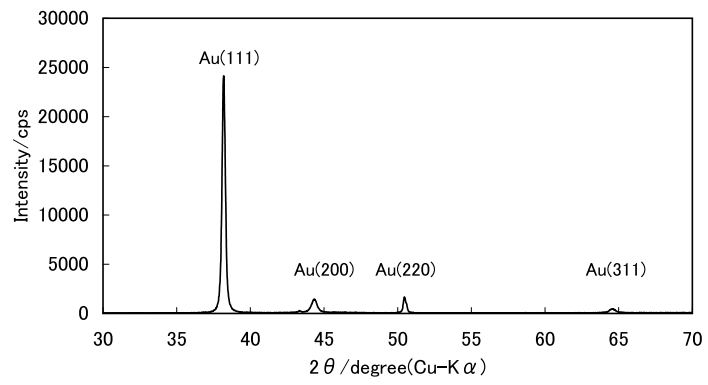

Fig. 9 X-ray diffraction pattern of electroless Au film from bath(1)+BTA+EDTA+en.

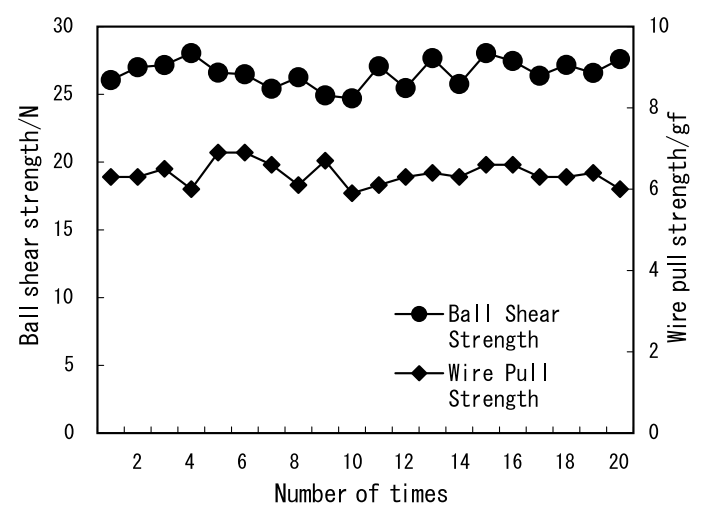

Fig.10 Ball shear strength and wire pull strength of electroless Au film.

たものである．強度の非常に強い（111）面の回折線が観測 されており, 金皮膜の回折パターンは, $\mathrm{Au}$ (111）に強く配 向していることが明らかになった.

\section{5 ボールシェア強度およびワイヤープル強度}

無電解金めっき浴（基本浴 $+\mathrm{BTA}+\mathrm{EDTA}+\mathrm{en}$ ）から得 た金めっき皮膜のボールシェア強度およびワイヤープル強度 の測定結果をFig.10に示す。なお，実装信頼性の観点から， ボールシェア強度としては $20 \mathrm{~N}$ 以上, また, ワイヤープル 強度としては7 gf 以上が，それぞれ望ましいと言われている. ボールシェア強度は, 平均で $25 \mathrm{~N}$ 以上の強度が得られ, 剥 離モードもすべてはんだボール内であった。 これは, 無電解 金めっきによる下地ニッケルめっきの腐食が抑制されたため, 接合時の Sn-Ni 合金層が正常に形成され ${ }^{7,8)}$, シェア強度なら びにはんだ剥離モードが安定したものと考えられる。一方， ワイヤープル強度については，市販浴から得られる金めっき

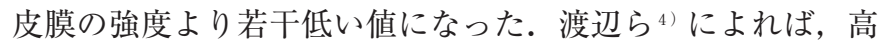
いボンディング強度を持つ無電解金皮膜は, $\mathrm{Au}(220), \mathrm{Au}$ （311）に配向すると報告している．本無電解金めっき浴から 
得られた金皮膜は $\mathrm{Au}$ （111）に強く配向し，皮膜外観も若干 粗いことから強度の低下が生じているものと推定される。 今 後は，金の結晶配向性や皮膜形態を制御する添加剤などの検 討が必要であると考えられる。

\section{4 結 論}

エリソルビン酸を還元郕とする無電解金めっきについて検 討した結果，以下のことが明らかになった。

1 ）金の析出は，チ才硫酸金錯イオンの還元反応とエリソ ルビン酸の酸化反応による電気化学的な反応で起こる ことが明らかになった．金および還元剤を除いたモデ ル浴の混成電位に抢ける交換電流密度から金の析出量 を算出したところ，実際のめっき浴の自己触媒反応に よる析出量とよく一致した。

2 ）エリソルビン酸ナトリウム濃度の増大に伴い，自己触 媒析出速度は増大し, 置換析出速度も増大する傾向が 認められた。

3 ）添加剤として用いたBTAは無電解金めっきの置換析 出反応を抑制した. EDTA と BTAを併用添加すると 置換析出速度は増大した。一方, en, BTA 㧍よび
EDTAを併用添加すると自己触媒析出速度は増大し， 置換析出速度は減少した。

4 ）本無電解金めっき浴から得た金めっき皮膜はボールシ エア強度を安定的に保ち, ニッケルめっきの腐食を抑 制する効果が確認された。

\section{文 献}

1) M. Dettke, Galvanotechik, 81, 2022 (1990).

2) Z. Mathe, Metal Finishing, 90, 33 (1992).

3) M. Kato, Y. Yazawa, and Y. Okinaka, Proc. 82th, AESF Technical Conference, p.805 (1995).

4) H. Watanabe, S. Abe, and H. Honma, J. Appl. Electrochem, 28, 525 (1998).

5）平塚昌子, 倉科 匡, 縄舟秀美, エレクトロニクス実装 学会誌, 5, 72 (2002).

6）加藤 勝, 新倉恵子, 星野重孝, 大野 湶, 表面技術, 42, 729 (1991).

7）山本健一，赤星晴夫，倉科 匡，野沢由美，木本良輔， 第 14 回マイクロエレクトロニクスシンポジウム論文集, p.77(2004).

8) T. Kurashina Y. Nozawa, N. Kaneko, N. Shinohara, and H. Nawafune, Electrochemistry, 73, 435 (2005) [in Japanese]. 